Zeszyty Naukowe Szkoły Głównej Gospodarstwa Wiejskiego

Ekonomika i Organizacja Gospodarki Żywnościowej nr 115, 2016: 37-57

Aldona Zawojska, Beata Horbowiec

Katedra Ekonomii i Polityki Gospodarczej

Szkoła Główna Gospodarstwa Wiejskiego w Warszawie

\title{
Ryzyko cenowe na rynku produktów rolno-żywnościowych: źródła, skutki i sposoby zarządzania
}

\section{Wstęp}

Jednym z najistotniejszych działów gospodarki narodowej większości krajów na świecie jest sektor rolno-żywnościowy. Zajmuje się on wytwarzaniem, gromadzeniem, przetwarzaniem, a także dystrybucją produktów pochodzenia rolniczego. Ze względu na swoją specyfikę poddany jest on oddziaływaniu wielu różnorodnych czynników natury: mikro-, mezo- i makroekonomicznej, społecznej, przyrodniczej oraz politycznej. Wśród nich za jedne z najważniejszych uznaje się rynkowe ceny nabywanych i sprzedawanych produktów. Analizując wielowymiarowość tego sektora, można dostrzec różnego rodzaju zagrożenia oraz ryzyko występujące $\mathrm{w}$ łańcuchu rolno-żywnościowym, wpływające na funkcjonowanie uczestniczących w nim podmiotów oraz wysokość osiaganych przez nie dochodów. Ryzyko w sektorze rolno-żywnościowym nie stanowi jednak wyłącznie problemu jego pojedynczych podmiotów; może ono skutkować nieefektywną alokacją czynników wytwórczych w całej gospodarce narodowej, przyczyniając się do obniżenia ogólnego bogactwa kraju.

Gwałtowne wahania cen stanowią zasadniczy element niepewności i niepokoju zarówno wśród producentów, jak i konsumentów, zwłaszcza gdy dotyczą żywności lub surowców, od których zależy bezpieczeństwo żywnościowe i zapewnienie środków do życia licznych społeczeństw.

W przededniu II wojny światowej John Maynard Keynes [1938] pisał: „Wahania cen głównych surowców, które są produkowane i sprzedawane w warunkach nieograniczonej konkurencji są dość zdumiewające”. Wahania cen nie były jednak wówczas aż tak znaczne, jak ich bezprecedensowe fluktuacje na globalnych rynkach towarowych w czasie kryzysu cenowego lat 2007-2008 oraz ostat- 
niego globalnego kryzysu finansowego i wielkiej recesji. Problem nadmiernej niestabilności cen produktów pierwotnych nie należy wyłącznie do współczesnych. Rynki tych produktów są strukturalnie narażone na głęboką nierównowagę: naprzemienne nadwyżki i niedobory podaży, z chwiejnością cen, która z perspektywy wieków wydaje się być trwałą cechą sektora pierwotnego ${ }^{1}$ (w tym rolnictwa) w odróżnieniu od innych sektorów. Jak zaznaczają Czyżewski i Stępień [2011], rolnictwo narażone jest na stosunkowo duże ryzyko wahań podaży i cen ze względu na swoiste właściwości ziemi jako czynnika produkcji. Inni autorzy [Wang i Barrett 2007] uważają, że sektor rolny jest bardziej wrażliwy na ryzyko cenowe ze względu na to, że wytwarzane przez niego produkty w mniejszym stopniu nadają się do magazynowania (przechowywania) niż wyroby przemysłowe. Ponadto zróżnicowanie produktów rolnych jest relatywnie mniejsze, a podmioty je wytwarzające liczniejsze [Carter i Gunning-Trant 2010].

Na przestrzeni dziejów niekorzystne skutki cykli rolnych były ograniczane głównie poprzez scentralizowaną redystrybucję produktów. Już w starożytnych miastach greckich i rzymskich (od czasów cesarza Oktawiana Augusta do upadku imperium) nadzór nad podażą i dystrybucją zbóż powierzano urzędnikowi publicznemu (tzw. praefectus annonae). Urzędy prefekta przetrwały, pod różnymi nazwami, przez okres średniowiecza aż do początku nowożytnej ery. Te ważne funkcje pełnił zarząd spichlerzy publicznych, które funkcjonowały jako zapasy buforowe, gromadząc zboże w latach obfitości, aby je redystrybuować w latach niedostatku. Z praktyki tej zrezygnowano dopiero w XVIII i XIX wieku wraz ze stopniowym powstawaniem i z rozpowszechnianiem się doktryny wolnego handlu [Fantacci 2012, Fantacci i in. 2012]. Konkurencyjne rynki towarowe niewątpliwie przynoszą korzyści poprzez zmniejszenie rent ekonomicznych, promowanie innowacji i zwiększanie produktywności. Są one jednak zawodne m.in. w uniknięciu cykliczności produkcji, z którą wiążą się wahania cen rynkowych.

\section{Cele, metody i źródła badań}

Głównym celem artykułu jest zidentyfikowanie przyczyn, skutków i metod ograniczania ryzyka cenowego występującego na rynku produktów rolno-żywnościowych. W zrealizowaniu tego zamierzenia pomogło wyznaczenie celów

\footnotetext{
${ }^{1}$ Trójpodział gospodarki narodowej na sektory: (1) pierwotny, (2) przetwórczy i (3) usług, zaproponowany został m.in. przez Nicholasa Kaldora [1967] do analizy etapów rozwoju gospodarczego kraju. Do sektora pierwotnego (pierwotnej działalności gospodarczej) zaliczył on: rolnictwo, łowiectwo, leśnictwo, rybołówstwo, rybactwo, górnictwo i kopalnictwo, a więc pozyskiwanie surowców naturalnych. Wcześniej rozróżnienia między produkcją pierwotną, wtórną i tercjalną dokonali Allan Fisher [1939] oraz Colin Clark [1940].
} 
szczegółowych: dokonanie przeglądu ekonomicznych koncepcji ryzyka, zlokalizowanie źródeł ryzyka cenowego, umiejscowienie rynkowego ryzyka cenowego wśród innych rodzajów ryzyka w sektorze rolno-żywnościowym ze wskazaniem mechanizmu transmisji tego ryzyka w ramach łańcucha dostaw żywności; zbadanie stabilności w czasie cen produktów rolnych w Polsce oraz przedstawienie głównych tendencji wykorzystania sposobów i instrumentów ograniczających ryzyko cenowe i jego skutki.

Wykorzystano metodę studium literatury naukowej oraz analizy statystycznej bazującej na danych GUS. Jako że za podstawę do oceny ryzyka cenowego najczęściej przyjmuje się zmienność historyczną (ex post) cen [Stańko i Hamulczuk 2009], do oszacowania ryzyka cenowego posłużyły współczynniki zmienności łańcuchowych indeksów cen globalnej produkcji rolniczej oraz indeksów nominalnych cen sprzedaży wybranych produktów rolnych w latach 1995-2013.

W badaniu własnym przyjęto m.in. za Allanem Willettem, że ryzyko jest tożsame z niepewnością wystąpienia określonego zdarzenia [Willet 1901].

\section{Ryzyko - ujęcie teoretyczne}

Ryzyko jako kategoria jest niejednolicie definiowane przez różne nauki i dyscypliny (np. ekonomię, zarządzanie, nauki prawne, nauki inżynieryjne, nauki przyrodnicze, nauki o bezpieczeństwie, nauki o zdrowiu, psychologię, statystykę, finanse i ubezpieczenia, teorie prawdopodobieństwa itp.), a niejednokrotnie również przez teorie $\mathrm{w}$ ramach poszczególnych nauk.

Pochodzenie terminu ryzyko sięga klasycznej greki - powiązanego z nawigacją słowa $\rho ı \alpha$, które oznaczało korzeń, skałę lub ucięty twardy ląd, stanowiącego metaforę ,przeszkody do uniknięcia na morzu"2.

Według większości źródeł angielskie słowo risk, podobnie jak włoskie słowa risico, rischio, hiszpańskie riesgo oraz francuskie risque, czy też portugalskie risco, pochodzą od łacińskich słów resicum, risicum, riscus i rischum oznaczających klif, rafy bądź urwisko, a w kontekście gospodarczym - zagrożenie, niebezpieczeństwo. Średniowieczne francuskie (walońskie) słowa resicq i risicq oraz katalońskie risc i reec, podobnie jak staroprowansalskie słowo rezegue, odnosiły się do możliwości uszkodzenia lub utraty towaru (podczas transportu drogą morską) [Aven 2014].

Willett, który przypuszczalnie jako pierwszy przedstawił ekonomiczną koncepcję ryzyka, utożsamiał je ze stopniem niepewności wystapienia niepożądanego zdarzenia (np. straty w przedsiębiorstwie), a nie ze stopniem jego prawdopo-

\footnotetext{
${ }^{2}$ Nawiązanie do przygód Odyseusza opisanych przez Homera w Odysei [Homer 2010].
} 
dobieństwa. Ryzyko według niego jest „obiektywnym korelatem” subiektywnej niepewności. Jest ono niepewnością w przebiegu wydarzeń w świecie (otoczeniu) zewnętrznym, której mniej lub bardziej wierną interpretację stanowi subiektywna niepewność [Willett 1901].

Podobnie Kenneth J. Arrow [1951] uznał ryzyko za jeden z wymiarów niepewności, rezygnując $\mathrm{z}$ definiowania i stosując zamiennie te dwa pojęcia.

Willett [1901] zaproponował podział ryzyk na dwie kategorie: ryzyko ekonomiczne związane $\mathrm{z}$ uczestnictwem $\mathrm{w}$ życiu gospodarczym oraz ryzyko pozaekonomiczne, którego istnienie nie wynika z działalności gospodarczej, ale może na nią wpływać. Ryzyko ekonomiczne dzieli na dynamiczne i statyczne.

Ryzyko dynamiczne jest związane z możliwością wystąpienia zmian w gospodarce. Jest skutkiem zmiennych uwarunkowań ekonomicznych (poziomu cen, preferencji i potrzeb konsumentów, skłonności do oszczędzania, technologii). Zwykle w dłuższej perspektywie przynosi korzyści całemu społeczeństwu. Z kolei ryzyko statyczne obejmuje niepożądane zdarzenia, które mogą nastąpić bez względu na zmiany w gospodarce (takie, jak wypadki, pożary czy klęski naturalne), a także jest powodowane błędami oraz bezprawną, przestępczą działalnością człowieka. Może ono być źródłem korzyści dla poszczególnych jednostek, ale zazwyczaj wiąże się z destrukcją aktywów i nie przynosi korzyści ogółowi społeczeństwa.

Ścisłe rozróżnienie między ryzykiem a niepewnością zostało wprowadzone przez Franka H. Knighta [1921], a zaproponowane przez niego definicje obu terminów są powszechnie akceptowane i wykorzystywane w badaniach i literaturze ekonomicznej. Właściwe ryzyko uznaje on za „mierzalną niepewność” lub „znaną szansę”, podczas gdy autentyczną niepewność ogranicza do przypadków niemierzalnych (typu nieilościowego). Praktyczna różnica między tymi dwiema kategoriami tkwi w tym, że w przypadku ryzyka znany jest rozkład wyników w grupie zdarzeń (za pośrednictwem obliczeń a priori lub statystyki bazującej na dotychczasowych doświadczeniach), co nie występuje w sytuacji niepewności, ponieważ w ogóle nie jest możliwe utworzenie grupy takich zdarzeń ze względu na wysoki stopień ich wyjątkowości (przypadkowości).

Według Davida Mandela [2007] ryzyko odnosi się do oczekiwanej straty związanej ze zdarzeniem. Mierzy się je poprzez połączenie wielkości i prawdopodobieństw wszystkich możliwych negatywnych skutków tego zdarzenia. Wiliam Lowrance [1976] również uważa, że ryzyko jest miarą prawdopodobieństwa i nasilenia niepożądanych efektów.

Mandel [2007] proponuje odróżnienie kategorii „ryzyko” od terminu „oczekiwana użyteczność danego zdarzenia”, którą szacuje się poprzez połączenie wielkości i prawdopodobieństwa wszystkich możliwych (zarówno negatywnych, jak i pozytywnych) oczekiwanych skutków określonego zdarzenia. Niepewność 
z kolei odnosi do stopnia zmienności możliwych efektów związanych ze zdarzeniem. Zdaniem Josepha Sinkeya [2002] niepewność jest odzwierciedlona przez nieoczekiwane zmiany danego zdarzenia.

Klasyczna teoria ekonomii bazuje na założeniu występowania pewności czy też pełnej wiedzy (braku niepewności). Reprezentuje ona podejście deterministyczne oraz ignoruje znaczenie pewnych zachowań gospodarczych poszczególnych jednostek, jak np. poszukiwanie przez nich informacji i radzenie sobie z niepewnością. Dzięki pracom Maurice'a Allaisa [1953], Kennetha Arrowa [1953, 1964, 1996] i Gérarda Debreu'ego [1953] nastąił rozwój teorii ekonomicznych, które tradycyjną analizę konkurencji i konkurencyjności poszerzyły o element niepewności (niedoskonałej wiedzy o przyszłości). Zakładają one, że istnieje ryzyko, dobra warunkowe $\mathrm{e}^{3}$ (ang. contingent commodities) lub roszczenia warunkowe (ang. contingent claims) czy też kontrakty (np. umowy o prace, umowy ubezpieczeniowe, instrumenty finansowe), w których ryzyko może być pośrednio lub bezpośrednio przenoszone $\mathrm{z}$ jednego podmiotu gospodarczego na inny. Zdaniem Arrowa [1953], aby wystapiły kompletne rynki ryzyka, musiałby jednak istnieć ,„świat, w którym istnieje tak szeroki wachlarz mechanizmów instytucjonalnych, że ludzie mogą wybrać dokładnie te ryzyka, które chcą ponosić oraz te, które chcą z siebie zrzucić". W przeciwieństwie do takiego ideału w realnym świecie funkcjonują rynki niekompletne (np. rynek kapitałowy, ubezpieczeniowy), a w rezultacie ograniczona jest możliwość zabezpieczenia się przed skutkami określonych rodzajów ryzyka, w tym przykładowo - ryzyka cenowego.

\section{Ryzyko cenowe, jego przyczyny i skutki}

Ryzyko cenowe, będące przedmiotem niniejszej pracy, jest - zgodnie z klasyfikacją Willetta - dynamicznym ryzykiem gospodarczym.

Wiąże się ono z niepewnością odnośnie poziomu i kierunku zmian cen otrzymywanych i płaconych [Stańko i Hamulczuk 2009].

Zdaniem autorek niniejszej pracy ekspozycja na ryzyko cenowe wiąże się nie tylko z poziomem cen, ale także z wolumenem obrotów (im większa ilość zakupionych bądź sprzedanych towarów przy braku zarządzania ryzykiem, tym

\footnotetext{
${ }^{3}$ Są to dobra, których użyteczność zależy od stanu natury (całkowitego opisu możliwych źródeł niepewności, przy czym pierwszym stadium natury jest niepewność, a drugim - rozwiązanie niepewności i skonkretyzowanie stanu natury). Konsument/producent nabywając dane dobro, nie zna jego przyszłej użyteczności, uzależnionej od wystappienia danego stanu natury. Przykładem dobra warunkowego jest zakupiony towar już wytworzony, którego dostawa ma się odbyć w przyszłości (np. transportowany statkiem, a więc jego dostarczenie zależy od dopłynięcia stat$\mathrm{ku})$. Roszczeniem warunkowym są przykładowo opcje.
} 
większe skutki ryzyka) oraz horyzontem czasowym (np. im dłuższy okres pomiędzy momentem zawarcia kontraktu a momentem sprzedaży, tym większe ryzyko).

Przed umiejscowieniem ryzyka cenowego wśród innych rodzajów ryzyka w sektorze rolno-żywnościowym warto odwołać się do genezy tego zjawiska we współczesnej gospodarce Polski. Do 1989 roku ryzyko cenowe było relatywnie mniejsze niż obecnie ze względu na istnienie systemu gospodarki centralnie sterowanej (planowanej) oraz odgórnego trybu wyznaczania cen. Niezależnie od tego, czy ustalano je administracyjnie, ściśle kontrolowano, pośrednio regulowano, czy też pozwalano im swobodnie kształtować się na nielicznych enklawach wolnego rynku, w długim okresie wszystkie ceny miały rosnąć w zasadniczo zbliżonym tempie [Topiński 1989, Luszniewicz 2014]. Ponadto w gospodarce centralnie sterowanej państwo występowało w roli swego rodzaju ogólnego asekuratora, przejmującego na siebie całe ryzyko związane z działalnością poszczególnych podmiotów [Ratajczak 2009].

Jedną z pierwszych decyzji, od których rozpoczęto proces transformacji polskiej gospodarki po 1989 roku, była liberalizacja (uwolnienie) cen dóbr konsumpcyjnych i czynników produkcji, skutkująca bardzo dużą dynamiką ich wzrostu (szokiem cenowym) na początku lat 90. XX wieku.

Po początkowych przemianach ustrojowych, a następnie w trakcie akcesji Polski do Unii Europejskiej rynek był stabilizowany za pomocą różnych instrumentów ograniczających ryzyko cenowe, a jednocześnie pełniących rolę ,siatki bezpieczeństwa" na wypadek pogorszenia koniunktury w rolnictwie. Zaliczyć do nich można m.in.: ceny interwencyjne i minimalne, kontyngenty, cła, subwencje eksportowe. Większość tych metod stabilizujących poziom cen miała w zasadzie pozytywny wpływ na rozwój sektora rolno-żywnościowego, ale państwowa polityka wobec rolnictwa została podporządkowana wspólnej polityce rolnej UE. Konsekwencją członkostwa Polski w UE było zwiększenie ryzyka cenowego na skutek zniesienia ceł na artykuły pochodzące z państw należących do Wspólnoty. Dodatkowo nastąpiła większa liberalizacja rynku, w czym można również upatrywać przyczyny destabilizacji poziomu cen artykułów rolno-żywnościowych.

Kształtowanie się cen sprzedawanych produktów rolnych przedstawiają w sposób syntetyczny wskaźniki cen globalnej produkcji rolniczej. Wyrażają one zmiany średnich ważonych cen skupu i cen uzyskiwanych przez rolników na targowiskach, a obliczane są jako iloraz wskaźnika wartości i wskaźnika wolumenu, które uzyskuje się ze zbiorczych rachunków produkcji rolniczej. Istotne jest, że w globalnej produkcji rolniczej (podobnie, jak towarowej) w latach 1999-2003 uwzględniono dopłaty bezpośrednie Agencji Rynku Rolnego do interwencyjnego skupu pszenicy i żyta, a od 2004 roku naliczone za dany rok płatności 
uzupełniające do powierzchni upraw (m.in. zbóż) [GUS 2015], które w pewnym stopniu mogą zniekształcać obraz zmienności cen rynkowych.

Analizując zmienność indeksów cen globalnej produkcji rolniczej w Polsce w latach 1995-2013 (tab. 1), zauważa się to, co w gruncie rzeczy jest potwierdzone w literaturze dotyczącej Polski [Hamulczuk 2014], UE [m.in. Tothova 2011] i krajów OECD [OECD 2009], że większe wahania cenowe występują w przypadku produkcji roślinnej niż zwierzęcej. Podobnie ceny skupu wybranych produktów rolnych pochodzenia roślinnego (pszenica, kapusta, liście tytoniu) wahały się w większym stopniu niż ceny produktów zwierzęcych (żywca wołowego i mleka). Istotne jest, że ryzyko cen niektórych produktów roślinnych przekłada się na ryzyko cen nakładów w produkcji zwierzęcej, a ryzyko cenowe produktów rolniczych - na ryzyko cenowe na rynku żywności (tab. 2).

\section{Tabela 1}

Zmienność historyczna cen produkcji rolniczej w Polsce w latach 1995-2013

\begin{tabular}{|c|c|c|}
\hline \multirow[b]{2}{*}{ Wyszczególnienie } & \multicolumn{2}{|c|}{ Współczynniki zmienności [\%] } \\
\hline & $\begin{array}{c}\text { wskaźnik cen } \\
\text { (rok poprzedni = 1) }\end{array}$ & $\begin{array}{l}\text { logarytm naturalny } \\
\text { wskaźnika cen }^{*}\end{array}$ \\
\hline \multicolumn{3}{|c|}{ Globalna produkcja rolnicza } \\
\hline Suma & 7,8 & 176,9 \\
\hline roślina & 9,5 & 492,1 \\
\hline zwierzęca & 8,4 & 245,4 \\
\hline \multicolumn{3}{|c|}{ Przeciętne ceny roczne skupu } \\
\hline pszenica & 23,9 & 399,8 \\
\hline kapusta & 23,7 & 330,7 \\
\hline liście tytoniu & 20,7 & 370,2 \\
\hline żywiec rzeźny - bydło (bez cieląt) & 11,1 & 177,7 \\
\hline mleko krowie & 10,5 & 156,1 \\
\hline
\end{tabular}

*Logarytm naturalny wskaźnika cen odzwierciedla logarytmiczną stopę przychodu.

Źródło: Opracowanie własne na podstawie danych GUS.

Ryzyko cenowe jest jednym $\mathrm{z}$ wielu rodzajów ryzyka występujących $\mathrm{w}$ rolnictwie i całym sektorze rolno-żywnościowym. Ze względu na bogatą literaturę krajową w tym zakresie (m.in. Jerzak [2009], Stańko i Hamulczuk [2009], Wawrzynowicz i in. [2012], Florek i Czerwińska-Kayzer [2013], Rembisz [2013], Wicka [2013], Szymańska [2014], Sulewski [2015]) w artykule w sposób świadomy zrezygnowano $z$ dokładnego opisu jego poszczególnych rodzajów, zachęcając czytelników do zapoznania się z wymienionymi pozycjami literatury.

Alan Miller i inni [2004], rozpatrując źródła różnych rodzajów ryzyka, wobec których stoją rolnicy, umiejscawiają ryzyko cenowe (wahań cen) wśród 
Tabela 2

Proces transmisji zmienności cen (ryzyka cenowego) w łańcuchu dostaw żywności - przegląd literatury

\begin{tabular}{|c|c|c|c|c|c|}
\hline Źródło & Kraje & Okres & Produkty & Etapy łańcucha & $\begin{array}{l}\text { Kierunek transmisji zmienności } \\
\text { (wahań) cen }\end{array}$ \\
\hline $\begin{array}{l}\text { Khan i Helmers } \\
\text { [1997] }\end{array}$ & USA & 1970-1981 & $\begin{array}{l}\text { pasze (kukurydza), woło- } \\
\text { wina, drób, wieprzowina }\end{array}$ & $\begin{array}{l}\text { pasze - farma - handel hurtowy } \\
\text { - handel detaliczny }\end{array}$ & od dostawcy pasz do farmy \\
\hline $\begin{array}{l}\text { Natcher i Weaver } \\
\text { [1999] }\end{array}$ & USA & $1970-1983$ & wołowina & $\begin{array}{l}\text { bydło opasowe - żywiec wołowy } \\
\text { - hurt - handel detaliczny }\end{array}$ & $\begin{array}{l}\text { dwukierunkowy na wszystkich eta- } \\
\text { pach łańcucha }\end{array}$ \\
\hline $\begin{array}{l}\text { Buguk i inni } \\
\text { [2003] }\end{array}$ & USA & 1980-2000 & ryby (sum) & $\begin{array}{l}\text { pasze - farma - handel hurtowy } \\
\text { - handel detaliczny }\end{array}$ & $\begin{array}{l}\text { od dostawcy paszy do farmy; od } \\
\text { sprzedaży hurtowej do farmy; od } \\
\text { farmy do sprzedaży hurtowej }\end{array}$ \\
\hline $\begin{array}{l}\text { Apergis i Rezitis } \\
\text { [2003] }\end{array}$ & Grecja & 1985-1999 & produkty rolne & $\begin{array}{l}\text { nakłady rolnicze - produkcja rolni- } \\
\text { cza - handel detaliczny }\end{array}$ & $\begin{array}{l}\text { od dostawcy paszy do farmy; od } \\
\text { konsumenta do farmy }\end{array}$ \\
\hline $\begin{array}{l}\text { Zheng i inni } \\
{[2008]}\end{array}$ & USA & 1980-2004 & $\begin{array}{l}45 \text { artykułów spożyw- } \\
\text { czych }\end{array}$ & sprzedaż detaliczna & od farmy do sprzedaży detalicznej \\
\hline Rezitis [2010] & Grecja & 1988-2000 & $\begin{array}{l}\text { jagnięcina, drób, wołowi- } \\
\text { na, wieprzowina }\end{array}$ & farma - handel detaliczny & $\begin{array}{l}\text { od farmy do konsumenta; od kon- } \\
\text { sumenta do farmy }\end{array}$ \\
\hline $\begin{array}{l}\text { Alghalith } \\
\text { [2010] }\end{array}$ & $\begin{array}{l}\text { Trinidad } \\
\text { i Tobago }\end{array}$ & 1974-2007 & koszyk żywności & $\begin{array}{l}\text { krajowy rynek ropy naftowej- } \\
\text { handel detaliczny }\end{array}$ & $\begin{array}{l}\text { od dostawcy ropy naftowej do kon- } \\
\text { sumenta żywności }\end{array}$ \\
\hline $\begin{array}{l}\text { Seremak-Bulge } \\
\text { i Rembeza } \\
\text { [2010] }\end{array}$ & Polska & 1990-2009 & mleko, mięso, zboża & $\begin{array}{l}\text { producent - przetwórca (handel } \\
\text { hurtowy) - handel detaliczny }\end{array}$ & $\begin{array}{l}\text { na ogół od cen surowców, poprzez } \\
\text { ceny zbytu w zakładach przetwór- } \\
\text { czych, po ceny detaliczne }\end{array}$ \\
\hline $\begin{array}{l}\text { Uchezuba } \\
{[2010]}\end{array}$ & RPA & $2000-2008$ & mięso drobiowe & farma - sprzedaż detaliczna & od farmy do sprzedaży detalicznej \\
\hline $\begin{array}{l}\text { Khiyavi i inni } \\
\text { [2012] }\end{array}$ & Iran & $1997-2010$ & drób & $\begin{array}{l}\text { dostawca pasz - farma - handel } \\
\text { detaliczny }\end{array}$ & \begin{tabular}{|l|} 
od dostawcy pasz do farmy; od \\
sprzedaży detalicznej do farmy \\
\end{tabular} \\
\hline $\begin{array}{l}\text { Nazlioglu i inni } \\
\text { [2013] }\end{array}$ & świat & 1986-2011 & $\begin{array}{l}\text { pszenica, soja, kukury- } \\
\text { dza, cukier }\end{array}$ & $\begin{array}{l}\text { rynek ropy naftowej - rynek towa- } \\
\text { rów rolnych }\end{array}$ & $\begin{array}{l}\text { od cen ropy naftowej do cen soi, } \\
\text { pszenicy i kukurydzy, ale tylko po } \\
\text { kryzysie (2006-2011) }\end{array}$ \\
\hline
\end{tabular}

Źródło: Opracowanie własne na podstawie Nazlioglu i inni [2013] oraz Assefa i inni [2015]. 
ryzyka produkcyjnego (powodowanego warunkami pogodowymi, chorobami zwierząt, inwazją szkodników itp.), ryzyka losowego/katastroficznego (np. pożaru, powodzi, wichur, kradzieży), ryzyka technologicznego (wynikającego z ciągłego rozwoju i stosowania nowych technik i metod produkcji np. nowych odmian roślin, środków chemicznych, mieszanek paszowych), niepewności prawnej (np. możliwość procesów sądowych, postępowań egzekucyjnych) oraz niepewności osobistej (choroby, urazy, śmierć).

Zlokalizowanie źródeł ryzyka odnoszącego się do cen produktów rolno-żywnościowych może bazować przynajmniej na dwóch kryteriach, którymi są: (1) wewnętrzne i zewnętrzne uwarunkowania rynkowe oraz (2) ogół czynników kształtujących poziom cen tych produktów.

Ryzyko cenowe objawiające się na rynku produktów rolno-żywnościowych może mieć źródła zarówno egzogeniczne (np. szoki podażowe związane z pogodą i klimatem, zmienność cen nakładów, embarga handlowe, otoczenie makroekonomiczne), jak też endogeniczne (dynamika procesów dostosowawczych na rynku). Do ryzyka wywołanego czynnikami natury makroekonomicznej (o szczególnym nasileniu nie tylko na rynkach produktów rolnych i dóbr żywnościowych, ale w całym sektorze rolno-żywnościowym) należy ryzyko instytucjonalne (np. zmiany w polityce gospodarczej, w tym fiskalnej i monetarnej) [Cevik i Sedik 2011, Zawojska 2012] oraz ryzyko kursowe [Poczta 2014].

Drugim pomocnym podejściem odnośnie umiejscowienia źródeł ryzyka cenowego jest kompleksowe spojrzenie na ogół czynników wpływających na poziom cen produktów rolno-spożywczych (rys.). Ze względu na ich wielorakość można przyjąć, że ryzyko cenowe jest wypadkową zjawisk i procesów występujących zarówno na poziomie producenta i konsumenta, jak też całej gospodarki narodowej i gospodarki globalnej. Stabilność cen lub jej brak są uzależnione zatem od równowagi zachodzącej wśród wpływających na nie czynników. Każde zakłócenie zjawisk i procesów może potęgować brak stabilności sektora rolno-żywnościowego, a tym samym zwiększać występujące $\mathrm{w}$ jego ramach ryzyko (produkcyjne, rynkowe, transakcyjne, przyrodnicze, technologiczne, instytucjonalne, kursu walut $\mathrm{i}$ inne).

Część autorów podkreśla wagę tradycyjnych agronomicznych determinantów cen produktów rolnych i żywności (np. rolę zapasów oraz ich dopasowania do zmian popytu i podaży), inni - zjawisk makroekonomicznych, a jeszcze inni-znaczenie rynków terminowych w oddziaływaniu na ceny spot tych produktów. Niektórzy badacze wyraźnie sugerują że to właśnie uczestnicy rynków finansowych, $\mathrm{w}$ tym terminowych, a zwłaszcza spekulanci są odpowiedzialni za nienaturalne wahania cen towarów. Czyni się ich winnymi m.in. za wywołanie kryzysu cenowego na światowym rynku ropy naftowej i żywności w latach 2006-2008 [Zawojska 2010, 2011, UNCTAD 2011, Russi 2013, Hajdukiewicz 2014]. 


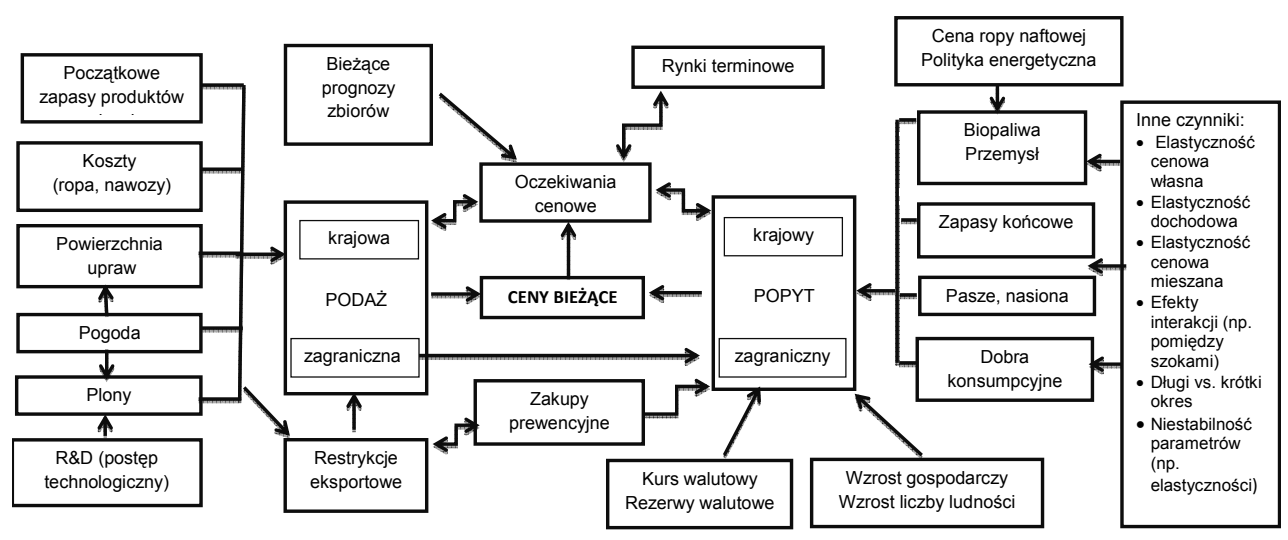

\section{Rysunek}

Czynniki kształtujące ceny produktów rolno-żywnościowych

Źródło: Opracowanie własne na podstawie Headey i Fan [2010, s. 5].

Oponenci tego stanowiska [Irwin i Sanders 2012] podkreślają korzyści „finansyzacji” rynków rolnych czy też sekurytyzacji aktywów bazujących na surowcach rolnych (np. zwiększenie płynności rynku, ułatwienie zabezpieczenia się przed ryzykiem i odkrywanie $\mathrm{cen}^{4}$ ), ponieważ pozwala ona nabywcom i sprzedawcom produktów rolnych na ujawnienie ich oczekiwań wobec ruchów cenowych. Derek Headey [2010] z kolei twierdzi, że dwiema najważniejszymi przyczynami ostatniego kryzysu żywnościowego (gwałtownego wzrostu cen) były interwencje rządowe zarówno po stronie podaży (np. restrykcje eksportowe), jak i popytu (np. międzyrządowe porozumienia importowe).

Całkowity wpływ ryzyka na poszczególne gospodarstwa rolne bądź też w ramach sektora rolno-żywnościowego zależy od powiązań między różnymi źródłami ryzyka. Współzależność czynników ryzyka (skorelowanie czasu i kierunku ryzyka) może znacznie się różnić, wpływając na ogólną ekspozycję na ryzyko poszczególnych podmiotów oraz całego sektora. Ryzyko cenowe należy do kategorii ryzyka systemowego, czyli silnie skorelowanego między producentami rolnymi w danym regionie lub kraju, gdyż wahania cen na rynku podobnie oddziałują na nich wszystkich.

Ryzyko cenowe (zmienność cen) pociagga za sobą wiele skutków, a wśród nich następujące:

\footnotetext{
${ }^{4}$ John M. Keynes tuż przed wielkim kryzysem twierdził, że przyszłość jest z natury zawsze obarczona niepewnością, a podmioty finansowe stawiające na przyszłość są podatne na zachowania stadne, które mogą wysyłać fałszywe sygnały cenowe i pogłębiać niestabilność gospodarczą.
} 
- wpływa na zmianę decyzji (popytowych, produkcyjnych, podażowych, inwestycyjnych itp.) [Tangermann 2011, Just i Pope 2013, Hernandez i in. 2014, Zhang 2015], zwłaszcza podmiotów mających awersję do ryzyka,

- powoduje nieefektywną alokację zasobów (np. poprzez wybór mniej ryzykownej produkcji, suboptymalne inwestycje produkcyjne) [Fafchamps 2004],

- transmituje się na inne etapy łańcucha - skutki uboczne dla całego sektora (tab. 2),

- generuje straty dla konsumentów i producentów [Newberry 1989, Figiel i Hamulczuk 2010],

- dostarcza premię (nadwyżkę) np. w formie dodatkowej marży na pokrycie kosztów związanych z niestabilnością cen [Finkelshtain i Chalfant 1991, Basu i Miffre 2013],

- generuje inne rodzaje ryzyka (np. dochodowe, upadłości) [Williams 2013],

- wpływa na wiarygodność kredytową podmiotu (powoduje wzrost wymagań banków wobec kredytobiorców np. odnośnie zabezpieczeń kredytów) [Ciaian i Kancs 2008],

- skłania narażonych na nie do zarządzania ryzykiem (zatrzymania, kontroli, transferu, dystrybucji ryzyka itp.), z którym związane są koszty transakcyjne [Williams 2014],

- powoduje migracje ludności wiejskiej (przypadek krajów rozwijających się) [Katz i Stark 1986, Lee 2015],

- wywołuje niepokoje społeczne w środowisku wiejskim [Jerzak 2009],

- jeśli jest relatywnie duże, to negatywnie wpływa na wielkość produkcji, a tym samym stope wzrostu gospodarczego, zwłaszcza w krajach słabo rozwiniętych [Aghion i in. 2005, Blattman i in. 2007],

- stanowi uzasadnienie interwencji państwowych (unijnych) [OECD 2011], z którymi związane są wydatki publiczne.

\section{Metody ograniczania ryzyka cenowego i jego negatywnych skutków}

Ograniczanie ryzyka cen towarów rolnych i żywności ma na celu przede wszystkim zapewnienie stabilności rynków tych produktów, a przez to i całego sektora rolno-żywnościowego.

Pojedynczy producenci rolni na ogół nie mają wpływu na poziom cen rynkowych (są cenobiorcami), a więc niewiele mogą uczynić aby zmniejszyć prawdopodobieństwo wystapienia wahań cen negatywnie wpływających m.in. na ich dochody. Mają oni jednak (przynajmniej z założenia) możliwość złagodzenia nie- 
korzystnych efektów ryzyka niestabilności cenowej, m.in. poprzez jego przeniesienie na inne podmioty (np. w formie ubezpieczeń) [Wicka 2013]; mogą również podjać działania $\mathrm{w}$ celu wyeliminowania lub ograniczenia zdarzeń powiązanych ze strata, czyli zmniejszyć zagrożenie nią (np. poprzez dywersyfikację upraw, różnicowanie działalności) [Kłoczko-Gajewska i Sulewski 2009]; mogą też podzielić się ryzykiem w ramach strategii kontraktów terminowych, funduszy wzajemnego inwestowania, współpracy w ramach grup producentów rolnych.

Zarządzanie ryzykiem niekorzystnej zmiany cen produktów rolnych umożliwiają giełdy towarowe [Belozertsev i in. 2011, Jerzak 2013]. W rozwiniętych gospodarkach rynkowych ryzyko cen towarów w obrębie łańcucha rolno-żywnościowego jest zasadniczo niwelowane przy użyciu produktów finansowych notowanych na giełdzie, takich jak kontrakty futures i opcje. W regionie Europy i Azji Środkowej istnieje ponad 200 czynnych giełd towarowych, ale większość z nich odgrywa raczej nieznaczną rolę w gospodarkach, gdyż wolumen obrotów produktami rolnymi, zwłaszcza w przypadku kontraktów terminowych, jest stosunkowo niski, a one same są słabo zintegrowane z systemem finansowym krajów.

Ogólnie rzecz biorąc, reakcją na ryzyko cenowe (powiązane z zagrożeniem stratami) może być jego:

- unikanie,

- zapobieganie,

- łagodzenie/dzielenie/przenoszenie (np. ubezpieczenia),

- podejmowanie i akceptowanie.

Tabela 3 ujmuje syntetyczne zestawienie metod zapobiegania ryzyku cenowe$\mathrm{mu}$, jego łagodzenia oraz reagowania ex ante i ex post na wiążące się z nim skutki.

Mimo tego, że spektrum potencjalnych metod i narzędzi zarządzania ryzykiem w rolnictwie jest szerokie, ich zastosowanie w Polsce zarówno na szczeblu gospodarstwa rolnego/domowego, jak rynku i państwa jest w zasadzie ograniczone. Część metod jest mało znana przez rolników, część rzadko jest przez nich stosowana lub w ogóle [Jerzak 2009].

$\mathrm{Z}$ przeglądu literatury wynika, że w polskich gospodarstwach rolnych podstawowym i tradycyjnym sposobem ograniczania skutków występowania działalności ryzykownych jest różnicowanie kierunków produkcji. Coraz powszechniejsza (m.in. dzięki wsparciu finansowemu z PROW) staje się również dystrybucja ryzyka poprzez tworzenie grup producentów rolnych (w tym w formie spółdzielni), których liczba (według rejestrów prowadzonych przez marszałków województw ${ }^{5}$ ) wynosiła około 1,3 tys. w 2015 roku.

\footnotetext{
${ }^{5}$ Ustawa z 17 listopada 2015 roku o zmianie ustawy o grupach producentów rolnych i ich związkach oraz o zmianie innych ustaw oraz ustawy o wspieraniu rozwoju obszarów wiejskich z udziałem środków Europejskiego Funduszu Rolnego na rzecz Rozwoju Obszarów Wiejskich w ramach Programu Rozwoju Obszarów Wiejskich na lata 2014-2020 (Dz.U. 2015, poz. 1888) z dniem
} 
Tabela 3

Sposoby ograniczania ryzyka i jego skutków

\begin{tabular}{|c|c|c|}
\hline $\begin{array}{l}\text { Gospodarstwo rolne/ } \\
\text { /domowe/wspólnota }\end{array}$ & Rynek & Państwo/rząd \\
\hline \multicolumn{3}{|c|}{ Zapobieganie ryzyku } \\
\hline $\begin{array}{l}\text { Wybór technologiczny } \\
\text { (np. systemy nawadniaja- } \\
\text { ce i odwadniajace; odpor- } \\
\text { ne odmiany roślin) } \\
\text { Wybór produktów z niska } \\
\text { ekspozycja na ryzyko (np. } \\
\text { objętych interwencja pu- } \\
\text { bliczna) }\end{array}$ & $\begin{array}{l}\text { Szkolenia i usługi w zakre- } \\
\text { sie zarządzania ryzykiem } \\
\text { Kontrakty forward }\end{array}$ & $\begin{array}{l}\text { Polityka makroekonomiczna } \\
\text { Zapobieganie chorobom i kata- } \\
\text { strofom (np. regulacje fitosanitar- } \\
\text { ne, ochrona przeciwpowodziowa) } \\
\text { Edukacja, doradztwo i informacja } \\
\text { związane z ryzykiem }\end{array}$ \\
\hline \multicolumn{3}{|c|}{ Łagodzenie ryzyka } \\
\hline $\begin{array}{l}\text { Dywersyfikacja produkcji } \\
\text { (upraw, zwierząt gospo- } \\
\text { darczych) } \\
\text { Unikanie ryzykownych } \\
\text { praktyk } \\
\text { Dzierżawa ziemi w zamian } \\
\text { za część zbiorów (crop } \\
\text { sharing) } \\
\text { Wzajemne fundusze } \\
\text { i ubezpieczenia } \\
\text { Spółdzielnie produkcyjne } \\
\text { i grupy producenckie } \\
\text { Lobbowanie na rzecz poli- } \\
\text { tyki wobec ryzyka }\end{array}$ & $\begin{array}{l}\text { Instrumenty rynku finan- } \\
\text { sowego (opcje, futures, } \\
\text { indeksowe polisy ubezpie- } \\
\text { czeniowe) } \\
\text { Ubezpieczenia (np. na wy- } \\
\text { padek wahań cenowych) } \\
\text { Integracja pionowa } \\
\text { Kontrakty produkcyjne } \\
\text { i handlowe } \\
\text { Dywersyfikacja finanso- } \\
\text { wania } \\
\text { Praca poza gospodar- } \\
\text { stwem } \\
\text { Szukanie alternatywnych } \\
\text { dostawców i nabywców }\end{array}$ & $\begin{array}{l}\text { Wsparcie rynkowo-cenowe (za- } \\
\text { kupy interwencyjne, zapasy bu- } \\
\text { forowe, subsydia eksportowe, cła } \\
\text { importowe) } \\
\text { Kwoty produkcji, set-a-side } \\
\text { System podatkowy „wygładzaja- } \\
\text { cy” dochody } \\
\text { Programy antycykliczne } \\
\text { Środki kontroli granicznej w przy- } \\
\text { padku wybuchu choroby zakaźnej } \\
\text { Subsydiowanie ubezpieczeń } \\
\text { Wspieranie działań w ramach } \\
\text { gospodarstwa rolnego majace na } \\
\text { celu ograniczenie ekspozycji na } \\
\text { ryzyko (subsydiowanie prywatne- } \\
\text { go magazynowania produktów, } \\
\text { kompensaty za wycofywanie pro- } \\
\text { duktu z rynku) }\end{array}$ \\
\hline \multicolumn{3}{|c|}{ Radzenie ze skutkami ryzyka } \\
\hline $\begin{array}{l}\text { Zaciaganie pożyczek od } \\
\text { sąsiadów i rodziny } \\
\text { Wewnatrzwspólnotowa } \\
\text { dobroczynność } \\
\text { Konsumowanie/nie sprze- } \\
\text { dawanie produktów } \\
\text { Protesty, petycje wobec } \\
\text { sektora publicznego i mię- } \\
\text { dzynarodowej społeczności }\end{array}$ & $\begin{array}{l}\text { Sprzedaż aktywów finan- } \\
\text { sowych i rzeczowych } \\
\text { Oszczędzanie/pożyczanie } \\
\text { Niespłacanie kredytów } \\
\text { Dochody spoza gospodar- } \\
\text { stwa }\end{array}$ & $\begin{array}{l}\text { Narzędzia ex ante wspomagające } \\
\text { rolników w łagodzeniu skutków } \\
\text { ryzyka lub radzeniu sobie z ry- } \\
\text { zykiem (płatności bezpośrednie, } \\
\text { wsparcie dywersyfikacji działalno- } \\
\text { ści, świadczenia socjalne) } \\
\text { Pomoc dotkniętym klęskami } \\
\text { żywiołowymi, embargiem handlo- } \\
\text { wym itp. }\end{array}$ \\
\hline
\end{tabular}

Źródło: Opracowanie własne na podstawie Zawojska [2002], Antón [2009], Stępień i Kułyk [2012], Lipińska [2013].

22 grudnia 2015 roku przeniosła kompetencje w zakresie prowadzenia rejestru grup producentów rolnych na dyrektorów oddziałów terenowych ARR. 
Transfer ryzyka jest na ogół dokonywany raczej za pomocą ubezpieczeń niż transakcji giełdowych, które nie są popularne wśród rolników. Do obowiązkowych należą jednak wyłącznie ubezpieczenia gospodarstwa rolnego i OC rolnika [Ustawa $z$ dnia 22 maja $2003 \mathrm{r}$.] oraz ubezpieczenia upraw rolnych (z dopłatą budżetu państwa do składki) przez rolników pobierających dopłaty bezpośrednie (obejmujące przynajmniej 50\% powierzchni upraw) [Ustawa $z$ dnia 7 lipca 2005 r., Rozporzadzenie Rady Ministrów...]. Producenci rolni nie mają wprawdzie możliwości ubezpieczenia się od ryzyka wahań cen z powodu braku takich ofert ze strony ubezpieczycieli, ale mogą dobrowolnie zabezpieczyć się przed poszczególnymi czynnikami wpływającymi na ich poziom (np. skutkami klęsk żywiołowych). Z powodu relatywnie wysokiego poziomu ryzyka strat $\mathrm{w}$ rolnictwie, firmy ubezpieczeniowe $\mathrm{w}$ Polsce $\mathrm{w}$ zasadzie nie są zainteresowane oferowaniem na zasadach rynkowych ubezpieczeń rolniczych, a i sami rolnicy często nie akceptują ubezpieczeń komercyjnych, na co wskazują m.in. Majewski i Sulewski [2011].

Ryzyko działalności rolniczej jest łagodzone m.in. poprzez zdobywanie dodatkowych dochodów z pracy poza gospodarstwem rolnym. W 2010 roku co trzecia osoba spośród 3,67 mln pracujących w rodzinnych gospodarstwach rolnych o powierzchni powyżej 1 ha pracowała dodatkowo $(3,2 \%)$ lub głównie $(31,2 \%)$ poza swoim gospodarstwem [GUS 2012].

Pomoc państwa w zakresie łagodzenia skutków ryzyka przybiera głównie formę kredytów preferencyjnych udzielanych ofiarom katastrof. Wpływ wahań cen rynkowych na dochody rolników jest hamowany przede wszystkim przez płatności bezpośrednie realizowane $\mathrm{w}$ ramach WPR, pełniące funkcję automatycznych stabilizatorów tych dochodów. Ze względu na to, że grupa beneficjentów płatności obszarowych jest bardzo liczna ${ }^{6}$, można uznać je za najpopularniejsze narzędzie interwencyjne wspomagające polskich rolników w łagodzeniu negatywnych skutków ryzyka cenowego.

\section{Podsumowanie}

Wahania cen - ich zmienność i nieprzewidywalność - są istotą wolnego rynku, w tym również swobodnie funkcjonujących rynków produktów rolnych i żywnościowych. Gdy stają się jednak nadmiernie duże i niespodziewane, mogą mieć negatywny wpływ na gospodarstwa rolne, przemysł przetwórczy, bezpieczeństwo żywnościowe (konsumentów) oraz całą gospodarkę narodową.

\footnotetext{
${ }^{6} \mathrm{~W} 2015$ roku wydano prawie 1,35 mln decyzji o przyznaniu rolnikom płatności bezpośrednich
} [ARiMR 2016]. 
Ryzyko cenowe w sektorze rolno-żywnościowym dotyczy niekorzystnych wahań cen nakładów wykorzystywanych w produkcji rolnej oraz niepewności odnośnie poziomu cen sprzedaży dóbr wytworzonych przez rolników. Relatywnie duża zmienność cen produktów rolno-żywnościowych jest zasadniczo powiązana $\mathrm{z}$ fundamentalnymi czynnikami kształtującymi podaż i popyt na rynkach tych produktów. Może być jednak wzmocniona przez uwarunkowania makroekonomiczne, polityczne i prawne działalności podmiotów oraz funkcjonowania rynków, spekulacje na terminowych rynkach towarów rolnych, a także w wyniku transmisji ryzyka w łańcuchu rolno-żywnościowym.

Mnogość czynników determinujących poziom i zmienność cen produktów rolnych stwarza trudność we wskazaniu skutecznego sposobu ograniczenia ekspozycji na ryzyko cenowe oraz łagodzenia jego negatywnych skutków. Ogólnie ujmując, problem nadmiernych wahań cen na rynkach produktów rolnych można rozwiązać na dwa sposoby. Pierwszym jest postępowanie z samą zmiennością cen poprzez działania stabilizujące rynki (np. kontrola cen i podaży), drugim postępowanie ze skutkami zmienności cen poprzez stosowanie narzędzi ex ante i ex post zarządzania ryzykiem (np. ubezpieczenia, zabezpieczenie się przed ryzykiem na rynkach terminowych, mechanizmy stabilizujące dochody rolników).

O ile problem ryzyka, w tym ryzyka cenowego, w polskim rolnictwie jest stosunkowo dobrze rozpoznany i opisany w literaturze, o tyle praktyczne jego rozwiązanie $\mathrm{w}$ formie wdrażania programów zapobiegających lub ograniczających ryzyko, jak też minimalizujących i rekompensujących jego negatywne efekty odbiega od zadowalającego stanu.

\section{Literatura}

AGHION P., ANGELETOS G.M., BANERJEE A., MANOVA K., 2005: Volatility and Growth: Credit Constraints and Productivity-Enhancing Investments, NBER Working Paper 11349.

ALGHALITH M., 2010: The Interaction Between Food Prices and Oil Prices, Energy Economics 32 (6), 1520-1522.

ALLAIS M., 1953: L'extension des théories de l'équilibre économique général et du rendement social au cas du risque, Econometrica 21 (2), 269-290.

ANTÓN J., 2009: Risk Management in Agriculture: A Holistic Conceptual Framework, OECD, Paris.

APERGIS N., REZITIS A., 2003: Agricultural Price Volatility Spillover Effects: The Case of Greece, European Review of Agricultural Economics 30 (3), 389-406.

ARiMR, 2016: Zrealizowane płatności obszarowe. Ptatności bezpośrednie - kampanie 2004-2013 - stan na dzień 30.06.2016, Warszawa. 
ARROW K.J., 1951: Alternative Approaches to the Theory of Choice in Risk-Taking Situations, Econometrica 19 (4), 404-437.

ARROW K.J., 1953: Le rôle des valeurs boursières pour la répartition la meilleure des risques, Économetrie. Colloques Internationaux du Centre National de la Recherche Scientifique 11, 41-47.

ARROW K.J., 1964: The Role of Securities in the Optimal Allocation of Risk-bearing, The Review of Economic Studies 31 (2), 91-96.

ARROW K.J., 1996: The Theory of Risk-Bearing: Small and Great Risks, Journal of Risk and Uncertainty 12, 103-111.

ASSEFA T.T. MEUWISSEN M.P.M., OUDE LANSINK A.G.J.M., 2015: Price Volatility Transmission in Food Supply Chains: A Literature Review, Agribusiness. An International Journal 3 (1), 3-13.

AVEN T., 2014: Risk, Surprises and Black Swans: Fundamental Ideas and Concepts in Risk Assessment and Risk Management, Routledge, London and New York.

BASU D., MIFFRE J. 2013: Capturing the Risk Premium of Commodity Futures: The Role of Hedging Pressure, Journal of Banking \& Finance 37 (7), 2652-2664.

BELOZERTSEV A., LAMON R., HOLLINGE F., 2011: Commodity Exchanges in Europe and Central Asia. A Means for Management of Price Risk, FAO Investment Centre, Working Paper 5.

BLATTMAN C., HWANG J., WILLIAMSON J.G., 2007: Winners and Losers in the Commodity Lottery: The Impact of the Terms of Trade Growth and Volatility in the Periphery, 1870-1939, Journal of Development Economics 82, 156-179.

BUGUK C., HUDSON D., HANSON D., 2003: Price Volatility Spillover in Agricultural Markets: An Examination of U.S. Catfish Markets, Journal of Agricultural and Resource Economics 28 (1), 86-99.

CARTER C.A, GUNNING-TRANT C., 2010: US Trade Remedy Law and Agriculture: Trade Diversion and Investigation Effects, Canadian Journal of Economics 43 (1), 97-126.

CEVIK S., SEDIK T.S., 2011: A Barrel of Oil or a Bottle of Wine: How Do Global Growth Dynamics Affect Commodity Prices?, International Monetary Fund, Working Paper $11 / 01$.

CIAIAN P., KANCS D’A., 2008: The Impact of Food Price Shock on Heterogeneous Credit Constrained Firms, Economics and Econometrics Research Institute, Research Paper Series 2.

CLARK C.G., 1940: The Conditions of Economic Progress, Macmillan, London.

CZYŻEWSKI A., STĘPIEŃ S., 2011: Ograniczanie ryzyka wahań cen i produkcji rolniczej w systemach ubezpieczeniowych, Prace Naukowe Uniwersytetu Ekonomicznego we Wrocławiu 168, 71-81.

DEBREU G., 1953: Une economie de l'incertain, Electricité de France Working Paper.

FAFCHAMPS M., 2004: Rural Poverty, Risk and Development, Edward Elgar Publishers, Chattenham.

FANTACCI L., 2012: Keynes's Commodity and Currency Plans for the Post-war World, [w:] M.C. Marcuzzo (red.) Speculation and Regulation in Commodity Markets: The Keynesian Approach in Theory and Practice, Sapienza University of Rome, 177-206. 
FANTACCI L., MARCUZZO M.C., ROSSELLI A., SANFILIPPO E., 2012: Speculation and Buffer Stocks: The Legacy of Keynes and Kahn, The European Journal of the History of Economic Thought 19 (3), 453-473.

FIGIEL S., HAMULCZUK M., 2010: Rozwój i aplikacja zaawansowanych metod analitycznych do ewaluacji ex-ante i ex-post efektów zmian we Wspólnej Polityce Rolnej $i$ w uwarunkowaniach makroekonomicznych (Synteza), IERiGŻ-PIB, Warszawa.

FINKELSHTAIN I., CHALFANT J.A., 1991: Marketed Surplus under Risk: Do Peasants Agree with Sandmo?, American Journal of Agricultural Economics 73 (3), 557-567.

FISHER A.G.B., 1939: Production, Primary, Secondary and Tertiary, Economic Record 15 (1), 24-38.

FLOREK J., CZERWIŃSKA-KAYZER D., 2013: Sposoby zarzadzania ryzykiem działalności gospodarczej w gospodarstwach rolnych, Roczniki Naukowe SERiA 15 (5), 70-75.

GUS, 2012: Pracujacy w gospodarstwach rolnych. Powszechny spis rolny 2010, Warszawa.

GUS, 2015: Rolnictwo w 2014 roku, Warszawa.

HAJDUKIEWICZ A., 2014: Przyczyny wzrostu światowych cen produktów rolno-spożywczych w pierwszej dekadzie XXI wieku, Prace Naukowe Uniwersytetu Ekonomicznego we Wrocławiu 369, 239-250.

HAMULCZUK M., 2014: Ryzyko cenowe a zmienność cen i relacji cenowych $w$ rolnictwie, Roczniki Naukowe Ekonomii Rolnictwa i Rozwoju Obszarów Wiejskich 101 (4), 54-67.

HEADEY D., 2010: Rethinking the Global Food Crisis: The Role of Trade Shocks, International Food Policy Research Institute, Discussion Paper 00958.

HEADEY D., FAN S., 2010: Reflections on the Global Food Crisis. How Did it Happen? How Has it Hurt? And How Can We Prevent the Next One?, International Food Policy Research Institute, Research Monograph 165.

HERNANDEZ M.A., IBARRA R., TRUPKIN, D.R., 2014: How Far Do Shocks Move Across Borders? Examining Volatility Transmission in Major Agricultural Futures Markets, European Review of Agricultural Economics 41 (2), 301-325.

HOMER, 2010: Odyseja, Wydawnictwo Zielona Sowa, Warszawa.

IRWIN S.H., SANDERS D.R., 2012: Financialization and Structural Change in Commodity Futures Markets, Journal of Agricultural and Applied Economics 44 (3), 371-396.

JERZAK M.A., 2009: Zarzqdzanie ryzykiem cenowym jako czynnik poprawy konkurencyjności gospodarstw rolnych w warunkach liberalizacji Wspólnej Polityki Rolnej UE, Zagadnienia Ekonomiki Rolnej 1, 13-23.

JERZAK M.A., 2013: Światowy towarowy rynek giełdowy; aktualny stan i tendencje w rozwoju, Problemy Rolnictwa Światowego 13 (28), 49-57.

JUST R.E., POPE R.D. (red.), 2013: A Comprehensive Assessment of the Role of Risk in U.S. Agriculture, Springer Science + Business Media.

KALDOR N., 1967: Strategic Factors in Economic Development, Cornell University, Ithaca, NY.

KATZ E., STARK O., 1986: Labor Migration and Risk Aversion in Less Developed Countries, Journal of Labor Economics 40 (1), 134-149.

KEYNES J.M., 1938: The Policy of Government Storage of Food-Stuffs and Raw Materials, The Economic Journal 48, 449-460. 
KHAN M.A., HELMERS G.A., 1997: Causality, Input Price Variability and Structural Changes in the U.S. Livestock-Meat Industry, paper submitted to Western Agricultural Economics Association Meeting, July 13-16, Reno, Nevada.

KHIYAVI P.K., MOGHADDASI R., ESKANDARPUR B., MOUSAVI N., 2012: Spillover Effects of Agricultural Products Price Volatilities in Iran (Case Study: Poultry Market), Journal of Basic and Applied Scientific Research 2 (8), 7906-7914.

KŁOCZKO-GAJEWSKA A., SULEWSKI P., 2009: Postawy rolników wobec ryzyka oraz sposoby jego ograniczania, Roczniki Nauk Rolniczych 96 (1), 141-148.

KNIGHT F.H., 1921: Risk, Uncertainty, and Profit, Hart, Schaffner \& Marx, Boston, MA.

LEE Y.N., 2015: Effect of Price Risk on Migration: Evidence from Ethiopian Rural Households, Selected Paper prepared for presentation at the 2015 Agricultural \& Applied Economics Association and Western Agricultural Economics Association Annual Meeting, July 26-28, San Francisco, CA.

LIPIŃSKA I., 2013: Prawne instrumenty zarzqdzania ryzykiem w rolnictwie, Przegląd Prawa Rolnego 1 (12) 67-84.

LOWRANCE W., 1976: Of Acceptable Risk. Science and the Determination of Safety, William Kaufmann, Los Altos, CA.

LUSZNIEWICZ J., 2014: Procesy inflacyjne w Polsce w latach 1945-1955 - przejawy, fazy, uwarunkowania, konsekwencje. Przyczynek do badań nad inflacja w PRL, Kwartalnik Kolegium Ekonomiczno-Społecznego Studia i Prace, Szkoła Główna Handlowa 2, 93-122.

MAJEWSKI E., SULEWSKI P., 2011: Rolnicy wobec ryzyka produkcyjnego i systemu ubezpieczenia upraw, Ubezpieczenia w Rolnictwie. Materiały i Studia 39, 23-44.

MANDEL D.R., 2007: Toward a Concept of Risk for Effective Military Decision Making, Defence R\&D Canada Technical Report DRDC Toronto TR 2007-124.

MILLER A.W., DOBBINS C., PRITCHETT J., BOEHLJE M., EHMKE C., 2004: Risk Management for Farmers, Purdue University Staff Paper 04-11.

NATCHER W.C., WEAVER R.D., 1999: The Transmission of Price Volatility in the Beef Markets: A Multivariate Approach, Selected paper presented at 1999 the American Agricultural Economics Association Annual Meeting, August 8-11, Nashville, Tennessee.

NAZLIOGLU S., ERDEM C., SOYTAS U., 2013: Volatility Spillover between Oil and Agricultural Commodity Markets, Energy Economics 36, 658-665.

NEWBERRY D.M., 1989: The Theory of Food Price Stabilization, The Economic Journal 99, 1065-1082.

OECD, 2009: Managing Risk in Agriculture: A Holistic Approach, OECD Publishing, Paris.

OECD, 2011: Risk Management in Agriculture: What Role for Governments? dostępne on-line na: https://www.oecd.org/agriculture/agricultural-policies/49003833.pdf.

POCZTA W., 2014: Wspólna waluta euro - potencjalne skutki jej wprowadzenia dla rolnictwa $w$ Polsce, Prace Naukowe Uniwersytetu Ekonomicznego we Wrocławiu, Agrobiznes, Problemy Ekonomiczne i Społeczne 360, 37-46.

RATAJCZAK M., 2009: Transformacja ustrojowa $w$ świetle ustaleń i zatożeń ekonomii instytucjonalnej, Ruch Prawniczy, Ekonomiczny i Socjologiczny 71 (2), 233-251.

REMBISZ W., 2013: Kwestie ryzyka, cen, rynku, interwencji i stabilności dochodów w rolnictwie, Vizja Press \& IT, Warszawa.

REZITIS A.N., 2010: Mean and Volatility Spillover Effects in Greek Producer-Consumer Meat Prices, Applied Economic Letters 10 (6), 381-384. 
Rozporzadzenie Rady Ministrów z dnia 30 listopada 2015 r. w sprawie wysokości dopłat do sktadek z tytulu ubezpieczenia upraw rolnych $i$ zwierzat gospodarskich $w 2016$ r. (Dz.U. 2015, poz. 2024).

RUSSI L., 2013: Hungry Capital: The Financialization of Food, Zero Books, Winchester.

SEREMAK-BULGE J., REMBEZA J., 2010: Zmiany cen i relacji cenowych na podstawowych rynkach żywnościowych, Zagadnienia Ekonomiki Rolnej 1, 112-125.

SINKEY J.F., 2002: Commercial Bank Financial Management in the Financial-services Industry, Prentice Hall, New Jersey.

STAŃKO S., HAMULCZUK M. (red.), 2009: Zarzqdzanie ryzykiem cenowym a możliwości stabilizacji dochodów producentów rolniczych - aspekty poznawcze i aplikacyjne, IERiGŻ-PIB 148, Warszawa.

STĘPIEŃ S., KUŁYK P., 2012: Zarzqdzanie ryzykiem cenowym w produkcji rolniczej, Roczniki Naukowe SERiA 14 (1), 486-491.

SULEWSKI P., 2015: Ekonomiczny wymiar ryzyka produkcyjnego w rolnictwie, Wydawnictwo SGGW, Warszawa.

SZYMAŃSKA E.J., 2014: Zarzqdzanie ryzykiem w produkcji żywca wieprzowego, Logistyka 6, 13811-13816.

TANGERMANN S., 2011: Risk Management in Agriculture and the Future of the EU's Common Agricultural Policy, International Centre for Trade and Sustainable Development, Issue Paper 34.

TOPIŃSKI A., 1989: Infacja a funkcjonowanie gospodarki polskiej, PWE, Warszawa.

TOTHOVA M., 2011: Main Challenges of Price Volatility in Agricultural Commodity Markets, [w:] I. Piot-Lepetit, R. M'Barek (red.), Methods to Analyse Agricultural Commodity Price Volatility, Springer-Verlag, New York, 13-29.

UCHEZUBA I.D., 2010: Measuring Asymmetric Price and Volatility Spillover in the South African Poultry Market, $\mathrm{PhD}$ thesis, Faculty of Natural and Agricultural Sciences, University of Free State, Bloemfontein, South African Republic, dostępne on-line na: http://scholar.ufs.ac.za:8080/xmlui/bitstream/handle/11660/2034/UchezubaDI. pdf? sequence $=1$.

UNCTAD, 2011: Price Formation in Financialized Commodity Markets: The Role of Information, UN, New York, Geneva.

Ustawa z dnia 17 listopada 2015 r. o zmianie ustawy o grupach producentów rolnych $i$ ich zwiqzkach oraz o zmianie innych ustaw oraz ustawy o wspieraniu rozwoju obszarów wiejskich z udziałem środków Europejskiego Funduszu Rolnego na rzecz Rozwoju Obszarów Wiejskich w ramach Programu Rozwoju Obszarów Wiejskich na lata 2014-2020 (Dz.U. 2015, poz. 1888).

Ustawa z dnia 22 maja 2003 r. o ubezpieczeniach obowiqzkowych, Ubezpieczeniowym Funduszu Gwarancyjnym i Polskim Biurze Ubezpieczycieli Komunikacyjnych (Dz.U. 2003 nr 124, poz. 1152 z późn. zm.).

Ustawa z dnia 7 lipca 2005 r. o ubezpieczeniu upraw rolnych i zwierzat gospodarskich (Dz.U. $2005 \mathrm{nr} 150$, poz. 1249 z późn. zm.).

WANG K., BARRETT C.B., 2007: Estimating the Effects of Exchange Rate Volatility on Export Volumes, Journal of Agricultural and Resource Economics 32 (2), 225-255. 
WAWRZYNOWICZ J., WAJSZCZUK K., BAUM R., 2012: Specyfika czynników ryzyka $w$ przedsiębiorstwach rolnych - próba holistycznego podejścia, Zarządzanie i Finanse 10 (1), 349-360.

WICKA A. (red.), 2013: Czynniki i możliwości ograniczania ryzyka w produkcji roślinnej poprzez ubezpieczenia, Wydawnictwo SGGW, Warszawa.

WILLETT A.H., 1901: The Economic Theory of Risk and Insurance, Studies in History, Economics and Public Law 14 (2).

WILLIAMS J., 2014: Agricultural Supply Chains and the Challenge of Price Risk, Routledge, New York.

ZAWOJSKA A., 2002: Narzędzia zarzqdzania ryzykiem w rolnictwie na przykładzie krajów Unii Europejskiej, Prace Naukowe Akademii Ekonomicznej we Wrocławiu, Agrobiznes Przemiany w Agrobiznesie i Obszarach Wiejskich oraz Ich Następstwa 941 (2), 532-544.

ZAWOJSKA A., 2010: Speculative Drivers of Agricultural Price Volatility and Food Insecurity, The 119th Seminar of EAAE "Sustainability in the Food Sector: Rethinking the Relationship between the Agro-Food System and the Natural, Social, Economic and Institutional Environments", Capri, Italia.

ZAWOJSKA A., 2011: Czy spekulacje finansowe wplywaja na międzynarodowe ceny towarów rolno-żywnościowych? Zeszyty Naukowe SGGW, Problemy Rolnictwa Światowego 11 (26), 177-192.

ZAWOJSKA A., 2012: Instytucje ekonomiczne i polityczne a ceny dóbr konsumpcyjnych, Roczniki Ekonomii Rolnictwa i Rozwoju Obszarów Wiejskich 99 (4), 7-28.

ZHANG D., 2015: The Trade Effect of Price Risk: A System-wide Approach, Empirical Economics 48 (3), 1149-1167.

ZHENG Y., KINNUCAN H.W., THOMPSON H., 2008: News and Volatility of Food Prices, Applied Economics 40 (13), 1629-1635.

\section{Abstrakt}

Celem artykułu jest zidentyfikowanie przyczyn i skutków ryzyka cenowego występującego na rynku produktów rolno-żywnościowych, jak też sposobów jego ograniczania. Zastosowano metodę studium literatury naukowej oraz analizy statystycznej bazującej na danych GUS przy wykorzystaniu współczynników zmienności indeksów cen rolniczej produkcji globalnej oraz indeksów cen skupu wybranych produktów rolnych w Polsce w latach 1995-2013. Badania własne potwierdzają uzyskane przez innych autorów wyniki, że większe wahania cenowe występują w przypadku produkcji roślinnej niż zwierzęcej. Przegląd badań empirycznych wskazał, że zmienność cen nakładów i produktów rolnych jest transmitowana wzdłuż łańcucha dostaw żywności, przez co wszyscy jego uczestnicy narażeni są na ryzyko cenowe. Reakcją na niepewność i ryzyko mogą być zarówno instrumenty stabilizacji rynków rolnych, jak też prywatne i publiczne zarządzanie ryzykiem.

Słowa kluczowe: ryzyko cenowe, sektor rolno-żywnościowy, produkty rolne 


\title{
Price risk in agri-food market: sources, effects and managing methods
}

\begin{abstract}
This paper aims to identify the causes and consequences of price risk in agri-food market as well as its mitigation methods. The research uses the scientific literature review approach and statistical analysis, applying the coefficients of variation of price indices for the global agricultural production and for the procurement of particular agricultural products in Poland over the period from 1995 to 2013. The price data is derived from the Central Statistical Office of Poland (GUS). Our study confirms the findings of other investigators that crop production is characterised by larger price fluctuations than animal production. An overview of empirical research shows that the volatility of agricultural input and output prices is transmitted along the food supply chain, thus exposing all its participants to price risk. In order to response to agricultural price uncertainty and volatility, instruments stabilizing agricultural markets as well as public and private risk management tools can be applied.
\end{abstract}

Key words: price risk, agri-food sector, agricultural products 